\title{
COMBATING SMUGGLING IN PERSONS: A MALAYSIA EXPERIENCE
}

\author{
Dr. Rohani Abdul Rahim, Muhammad Afiq bin Ahmad Tajuddin \& Kamaruddin bin Hj. Abu Bakar \\ Faculty of Law \\ Universiti Kebangsaan Malaysia
}

\author{
and \\ Mohammad Nizamuddin Bin Abdul Rahim \\ Faculty of Business and Entrepreneur \\ Universiti Malaysia Kelantan
}

\section{ABSTRACT}

Malaysia continues to face various challenges derived from the widespread of international migratory movement because of various economic reasons. Malaysia strategic geographical location, in the center of the South East Asian region made the country an attractive destination for human smuggling and trafficking in persons activities. Some of the smuggled persons may end up being trafficked victims base on the definition adopted by Malaysian laws on "trafficked victims". Malaysia Anti-Trafficking in Persons and Anti-Smuggling of Migrants Act 2007 (Amendment 2010) affords continuous protection for "smuggled turn trafficked" victims. On the other hand, smuggling is an offence under the said law because it threatens not only the public safety but also the national security. For the same reason smuggling also should be seen as a threat to Malaysia security and justifies for stern consideration and actions. Constant reviews on the loop-holes in the legal provisions and the available mechanism will minimize the possible injustice that may incur while enforcing the said Act.

This paper will draw on the challenges faced by Malaysia government in combating and preventing smuggling activities, and by making these efforts will strengthen the country peace and security.

Keywords: Combating, prevention, smuggling in persons, trafficked victims and state security.

\section{INTRODUCTION}

Trafficking in persons and smuggling activities has been reported to be the largest illegal lucrative business in the world replacing trading of drugs and arms (Department of States, 2013). The impact from this illegal activities affects the security of the country, the economy and the society at large. At present, Malaysia economic stability and its strategic location have been attracting people from all corners of the world and has opened doors to both trafficking in persons and human smuggling. 
Malaysia was placed in the most precarious situation for trafficking in persons (tier 3) in the 2007 and 2009. Since then, plenty of initiatives have been undertaken by the Malaysian government in order to respond and concurrently overcome the phenomenon. This placement is based on the extent of government action to combat trafficking and the size of the problem that are, on the extent of governments' efforts to reach compliance with the TVPA's minimum standards for the elimination of trafficking in persons, which are consistent with the Palermo Protocol.(Department of States, 2013).

In 2013, Malaysia has improved and was place in tier 2 watch-list until today(Department of States, 2013).This tier carries the meaning of full non-compliance of the government onthe TVPA's (Trafficking Victims Protection Act) minimum standards but are making significant efforts to bring themselves into compliance to it and ;a) the absolute number of victims of severe forms of trafficking is very significant or is significantly increasing; $b$ ) there is a failure to provide evidence of increasing efforts to combat severe forms of trafficking in persons from the previous year, including increased investigations, prosecution, and convictions of trafficking crimes, increased assistance to victims, and decreasing evidence of complicity in severe forms of trafficking by government officials; $c$ ) the determination that a country is making significant efforts to bring itself into compliance with minimum standards was based on commitments by the country to take additional steps over the next year.

This positioning is rather depreciating and may be refute if more information on these efforts to combat trafficking are make known to the interested parties. However issues in combating trafficking and smuggling of persons are complex and critical, therefore some of the information may be classified confidential when affecting the country security and may not be suitable to be disclosed worldwide.

Furthermore there is a thin line to differentiate trafficking and smuggling in persons because in smuggling of person, the victims may become trafficked victims if they are exploited such as being abuse, cheated, thereat, misrepresented, forged documents involved, than in this circumstances the one smuggled person turn into trafficked victim

\section{The Position of Smuggling of Person in Malaysia}

Smuggling in Person is internationally acknowledge as organized and transnational crime. Specifically under Nigerian Economic and Financial Crimes Commission Act 2004, smuggling and trafficking is part of the economic and financial crimes (Section 46 of the said Act). The definition of people smuggling 
(also called human smuggling) is provided by Article 3(a) of the Protocol against the Smuggling Migrants by Land, Sea and Air 2000 where it states

"the procurement, in order to obtain, directly or indirectly, a financial or other material benefit, of the illegal entry of a person into a State of which the person is not a national or a permanent resident.

Definition given by US Department People smuggling (also called human smuggling) is

"the facilitation, transportation, attempted transportation or illegal entry of a person or persons across an international border, in violation of one or more countries' laws, either clandestinely or through deception, such as the use of fraudulent documents" (US Department)

As defined under international law, human trafficking involves the use of threat of force or other forms of coercion and the giving or receiving payments or benefits for the purpose of exploitation. It occurs because of the exploitation and the difficulty that faced by the victims of human trafficking to report such crime due to lack of awareness. Smuggling is considered as a criminal act while trafficking in person involved a criminal act conducted on a trafficked victims. The differences between the two can be seen in the following table.

Difference between Trafficking in Persons and Smuggling of Migrants (United Nations Office on Drugs \& Crimes)

\section{TRAFFICKING IN PERSONS}

The instrument/international law involved is Protocol to Prevent, Suppress and Punish Trafficking in Persons, especially Women and Children under UN Convention on Transnational Organised Crime.

The main element to prove any offence relating to trafficking in persons is exploitation and it may happen in a country without being a cross-border offence. It may also happen at the domestic level.

Involving the elements of exploitation, manipulation, threat against victims. Continuous and repeated exploitation.

\section{SMUGGLING OF MIGRANTS}

The instrument/international law involved is Protocol against the Smuggling of Migrants by Land, Air and Sea under UN Convention on Transnational Organised Crime

The important element in the smuggling of migrants is the cross-border occurrence.

Involving consent of the smuggled persons and profits for the people smuggling syndicates. The smuggling activity ends upon arrival at the destination. 
In Malaysia smuggling of migrants cases increases every year and could not be easily be reflected by the statistics identified. They are sometimes calculated as triple the number of identified cases. This still could not reflect the smuggling problem that Malaysia is facing because the smuggled migrants are clandestine with the huge number oftrafficking victims cases that may reached 2 million or more a year. This can be evidenced in the following table.

\section{STATISTICS OF CASES FOR SMUGGLING OF MIGRANTS}

\subsubsection{0 until 30.11.2012}

\begin{tabular}{lllccc}
\hline$\overline{\text { Item }}$ & Matter & 2010 & 2011 & 2012 & Total \\
\hline$\overline{1 .}$ & Total Cases 3 & 22 & 44 & 69 & 1029 \\
$\overline{2 .}$ & No. of Smuggled Migrants & 1 & 516 & 495 & 89 \\
\hline 3. & No. of Arrested & 2 & 31 & 56 & \\
\hline
\end{tabular}

Source: Ministry of Home Affairs: Security Collective Responsibility-Statistics of Trafficking in Persons and Smuggling of Migrants 2012.

The reasons that make identifying smuggled migrants statistics a problem besides its clandestine nature to trafficking upon their exploitation are:

1. The long coastal area that needs be secured at all time,

2. The substantial number of entrance and exit points by air, land and sea,

3. Falsification of travelling documents by agents and international syndicates,

4. Overstayed migrants

5. Illegal entering into Malaysia via unidentified entry points,

6. Irresponsible and illegal agents,

7. Ignorant and uneducated migrants,

8. Migrant Family chain and network, and

9. Corrupt enforcers.

In the state of Sarawak, the authorities have identified 72 land routes for smugglers. These routes, cleared by border dwellers and illegal loggers, are known as "rates lates" or "lorong tikus" (Hosen, M.N). 


\section{The Malaysia Experience and Efforts in combatting Smuggling of Person.}

The government has made a great effort in combatting smuggling of persons. The main approach is to tackle the trafficking of person's problem in order to discourage the smuggling activities. However, to tackle the smuggling activities at the entrance points may lessen the number of trafficking in persons activities significantly.

Malaysia has developed Five-Year National Plan (2010-2015) to show to the world of Malaysia determination to combat trafficking in persons activities and to eliminate Malaysia negative image as transit from this inhumane activities. The plan consist of to strengthen the laws, coordination and cooperation internationally, to raise public awareness, conduct training in education and awareness programme, and strengthen law enforcement.

Malaysia is also committed to tackle the problem of trafficking in persons and share the concern of international community that there is an urgent need to accelerate global efforts to stop this scourge. The effort to combat trafficking in persons require integrated and comprehensive international cooperation through information and knowledge sharing and capacity building as well as the dialogues. Authorities in Malaysia also collaborate with the international bodies in offering programs such as counselling, training, access to medical service and reintegration into society for victims of trafficking. The Malaysian government has further assent the Protocol to Prevent, Suppress, and Punish Trafficking in Persons Especially Women and Children.

The establishment of the council for Anti Trafficking in Persons and Anti-Smuggling of Migrant (MAPO) which function to oversee the implementation of the act and to formulate policies and programs to combat trafficking in persons and smuggling in person is vital to enforce the implementation of the ATIP-SOM Act. The main objective is to make Malaysia internationally accredited as being free of illegal activities in connection with human trafficking and smuggling of migrants. MAPO and the Secretariat of Trafficking in Persons within the Home Ministry of Malaysia continued to coordinate the anti-trafficking response and awareness.

The plan consists of;

\section{a) To Strengthen laws via;}

i. Increase in penalties - fine for trafficking set at between RM500,000/ and RM1 Million, compared to the current penalty of between RM50,000/ to RM500,000/. 
ii. Address the issue of smuggling of migrants - One of the important aspects concerning the amendments to Anti Trafficking in Persons and Smuggling of Migrants (ATIPSOM) 2007 was to include all actions involved in acquiring or maintaining labour or services of a person through coercion. Nevertheless, there is a specific internal guideline that has been prepared amongst which non-payment of salary for three month would constitute as labour exploitation.

The Royal Malaysia Police is the main enforcement agency to combat the crime relating to the smuggling of person activities that were contained in penal code, Child Act 2001 and Immigration Act 1953.

\section{Coordination and Cooperation Internationally}

i. Malaysia has work closely with several countries such as United Kingdom, Australia and related international bodies namely International Organization for Migration (IOM) in conducting capacity building programs encompassing prevention, protection, prosecution and awareness.

ii. Signing of Memorandum of Understanding in Combating Transnational Crime - Malaysia views the threats of transnational crime very seriously due to the complexities of the crime. This is due to the fact that transnational crime would involve elements with regards to movement of people, financial transaction as well as involvement of organised crime syndicates. In this relation, trafficking in persons is one of the elements under organised crime and transnational crime. To ensure that this crime could be tackled effectively, Malaysia has signed Memorandum of Understanding on Transnational Crime/Security with strategic partners namely the Australia, United Kingdom, Saudi Arabia, United States and China. The MoU/Agreement provides for exchanges of information and intelligence between law enforcement agencies, capacity building program and exchange of best practices.

\section{Raise public awareness}

i. Conduct awareness through school, institute of higher learning and Media, Work with NGOs.

ii. Engagement with Non Governmental Organizations (NGO) / International Organization

iii. Engaging with NGO for the initiative of bringing jobs inside the shelters instead of allowing the victims to work outside the shelters. 
iv. Cooperating with the IOM and "e Suka Society " for counselling.

v. Collaboration with the „Rotary Club of Bandar Sunway " to provide health programs for shelter homes. Activities carried out were as follows:

vi. Health screening for victims, volunteers and supervisors;

vii. Health talk; o Screening for hepatitis disease control and o Basic life support course.

viii. Conducting various programmes for the trafficking victims such as English classes and psychological therapy class, Patchwork, cooking classes and necklace design in collaboration with NGOs.

ix. Collaboration with IOM in conducting "The Smile Buddy Program".

x. In order to develop occupational skills among the victims, Ministry of Women had conducted classes with collaboration by local companies.

\section{Conduct training in Education and Awareness Programme}

i. in its effort to educate employers and migrant workers, Malaysia Anti- Trafficking In Person Organisation (MAPO) had conducted such forums in Cameron Highland, Pahang and Penang in February and March 2012. During this forum, the employers have been informed about the ATIPSOM 2007 and the penalties which can be charged.

ii. Media and Publicity Committee continues the Awareness Campaign through electronic and printed media. They also conducted talk programmes in local radio and television stations.

iii. This committee also conducted 6 series of „Program Minda Setia 1 Malaysia' in order to create awareness among the mediator i.e. state information officers, state social officers and 1 Malaysia Community Committee members.

iv. National Council of Women Organisation (NCWO) also conducted numbers of Awareness Campaign as well as Training for Trainers (TOT) involves teachers, students, nurses, government officers and also NGOs.

v. Malaysia Council for Child Welfare (Majlis Kebajikan Kanak-Kanak Malaysia) has conducted dialogs among NGOs in order to combat trafficking in persons.

\section{b) To Strengthen law enforcement.}

i. Conducting awareness programmed for government offices

ii. Conducting and attending Investigation and Prosecution Training for all Enforcement Agency in the country and abroad.

iii. Provide discussion, forum, workshop and seminar for the Senior Government Official from the relevant agencies. 
The 3P programme by the Malaysia government is an effective measure can be example to other countries. (Bernama 2011)

(a) Prosecution

(i) Increase law enforcement actions under the anti-trafficking law, particularly labour trafficking cases;

(ii) Apply stringent criminal penalties to those involved in fraudulent labour recruitment or forced labour; and

(iii) Increase efforts to prosecute and convict public officials who profit from or are involved in trafficking, or who exploit victims.

(b) Protection

(i) Develop and implement procedures to identify labour trafficking victims among vulnerable groups such as migrant workers and refer them to available protection services;

(ii) Improve victim protection in government facilities by providing victims legal assistance, and provide effective counselling and care to the victims of trafficking;

(iii) Develop and implement mechanisms to allow adult foreign trafficking victims to travel, work, and reside outside of government shelters;

(iv) Provide legal alternatives to the removal of trafficking victims to countries in which they would face retribution or hardship; and

(v) Ensure that victims of trafficking are not threatened or punished for crimes committed as a result of being trafficked.

(c) Prevention

(i) Make greater efforts to educate migrant workers on their rights, and the legal recourse available, and how to seek remedies against traffickers or employers who fail to meet their legal obligations;

(ii) Re-negotiate memoranda of understanding with source countries to incorporate victim protection and remove authorisations for employers to confiscate passports or travel documents; 
(iii) Continue to train officials on the effective handling of sex and labour trafficking cases, with particular emphasis on victim protection and the identification of labour trafficking victims;

(iv) Make efforts to reduce the demand for both sex and labour trafficking; and

(v) Expand the anti-trafficking awareness campaign to encompass both labour and sex trafficking.

The Government has established several place of refuge to place victims of human smuggling and trafficking. The Victim will be protected at the places of refuge until the process of recording evidence is completed pursuant to section 44 and 51 of the Anti-Trafficking in Persons and Anti-Smuggling of Migrant Act 2007. The place of refuge is established to protect victims who have been issued with an interim protection order (IPO) and subsequently a protection order (PO) until the process of recording evidence is completed. The victims are provided with meals, accommodation, recreational activities, counselling and free to have their own activities. (Council of Anti-Trafficking in Persons and AntiSmuggling of Migrant Act 2007)

\section{OFFENCES OF SMUGGLING IN PERSONS IN MALAYSIAN LAW}

There are a number of laws that are applicable for purpose of combating smuggling of persons into the country. Smuggling activities are criminal offences. Arrested migrants upon investigation when determined exploited, they will be classified trafficked victims and treated accordingly. Otherwise, penalties laid out in these legal provisions will be made applicable to the offenders. This can be seen as identified in the following table.

\section{Human Smuggling}

\begin{tabular}{lll} 
Section & Offences & Penalty \\
\hline $26 \mathrm{~A}$ & Offences of Smuggling Migrants & On Conviction, \\
& Imprisonment not exceeding \\
& fifteen (15) \\
& Years and liable to a fine or \\
& Both
\end{tabular}

26B Aggravated offence of smuggling of

On conviction, Migrant involving imprisonment

(a) Intention to exploit the smuggled migrant not less than three (3) 
After entry into the receiving country or

Transiting country whether by the person

Himself or by another person

(b) Subjecting the smuggled migrant to cruel, Inhuman or degrading treatment; and

(c) The person's conduct give rise to a risk of death or serious harm to the smuggled migrant.

$26 \mathrm{C}$

Offence of bringing in transit or snuggled

Migrant through Malaysia by land, sea

Or air or otherwise arranging facilitating

Such act.

$26 \mathrm{D}$

Offence of profiting from the offence of

Smuggling of migrants. years but not exceeding

twenty (20) years and

liable to a fine or both
On conviction,

imprisonment not

less than seven (7)

years and liable to

a fine or both.

On conviction,

Imprisonment not less

Than seven (7) years

and not exceeding fifteen

(15) years and liable to a

Fine of not less than five

Hundred thousand ringgit

But not exceeding one

Million ringgit and shall

Be liable for forfeiture

Of the profits from the

offence.

\section{The Security Offences (Special Measures) Act 2012 (Act 747), (SOSMA)}

SOSMA is an act "to provide for special measures relating to security offences for the purpose of maintaining public order and security and for connected matters". The act says a police officer may, without warrant, arrest and detain any person whom he has reason to believe to be involved in security offences and that person may be detained for a period of 24 hours for the purpose of investigation. The 
police officer may extend the period of detention for a period of not more than 28 days, for the purpose of investigation. The police officer will have immediately notify the-next-of kin of the person of his arrest and detention and conditionally allow that person to consult a lawyer of his or her own choice. SOSMA is more lenient than the stricter Internal Security Act 1960 (ISA) in the sense the time frame (for detention) is longer and detainee could be held without trial. This act also gives the police more power to extent detention period in the event they need more time to investigate and determine the trafficked victims status on whether she is exploited or is an illegal or smuggled immigrant. The act also allow police and other enforcement agencies to intercept communications of suspended individuals without prior approval from the public prosecutor's office.

\section{AGENCIES FOR COMBATING TRAFICKING IN MALAYSIA}

The Malaysia government has institutionalized the ATIP-SOM 2007 by setting up the Council for AntiTrafficking in Person and Anti-Smuggling of Migrants (MAPO) to develop policies and strategize to combat this organized crime and collaborate with international and non-governmental agencies to prevent and try to achieve zero percentage of trafficking in the country. The Malaysian government and its agencies have been proactive and are open in discussion as well as bridging gap with NGOs and states implementing the National Action Plan against Trafficking in Persons (2010-2015). This action is a strategic direction for the next five years where the primary objectives is to combat trafficking in persons and enrich support programs as well as ensure the effective implementation of the strategic goals (Ministry of Home Affairs Malaysia).

\section{CONCLUSION}

Malaysia has put continuous efforts in combatting smuggling of person. Malaysia has a well written plan that can be followed in achieving the goal stated in ATIPSOM 2007(Amendment 2010).However, Malaysia is yet to realize the need to have standard and clear procedures in determining who are the smuggling criminals and the trafficked victims. Enforcement officers have to be trained to be able to decide on the status of the arrested persons for purpose of providing justice to exploited migrants. Experiences in handling smuggled persons is significant to ensure only illegal migrants penalized not otherwise. Malaysia too need to join regional co-operations on bi-lateral and multi-lateral basis to ensure close co-operations as a supplement to domestic action to deter smuggling of persons. The Bali Process resulted people smuggling to become a crime in both Indonesia and Malaysia now. Training initiatives to improve the skills of border and immigration officers are prominent not only at domestic level but also regionally. 
On that note prevention of smuggling in persons could be minimized and protection of trafficked victims could be upheld.

\section{REFERENCES}

Ashgar Ali, Farheen Baig, Muzaffar Syah \& Mohammad Naqib (2013), Foreign Workers: The Law And Practice in Malaysia, CLJ Publiction, 2013.

Bernama, US Ambassador Lauds Malaysia's Anti-Migrant Smuggling Efforts date 27th October 2011

Asis, M. M. B. (2008). Human Trafficking in East and South-East Asia: Searching for structural factors In E. N. Sally Cameron (Ed.),Trafficking in humans: Social, cultural and political dimensions. New York: United Nations University Press.

Bales, K., \& Soodalter, R. (2010).The slave next door: Human trafficking and slavery in Americatoday: University of California Press.

Buzan, B. (1991). New Patterns of Global Security in the Twenty-first Century. International Affairs, 67.3 432-433.

Buzan, deWilde, \& Weaver. (1998).Security: A New Framework for Analysis: Boulder, CO: Lynne Rienner.

Council of Anti-Trafficking in Persons and Anti-Smuggling of Migrant Act 2007. http://mapo.bernama.com/index.php

Department of States, United States of America. Trafficking in Persons Report, 2013,http: //www .state. gov/documents/organization/210737.pdf

Emmers, R. (2004). Non-Traditional Security In The Asia-Pacific, The Dynamics of Securitization: Eastern Universities Press, Marshall Cavendish.

E.Sachs, S. (2003). The Changing Definition of Security.International Relations. Flamm, M. (2003). Exploited, Not Educated Trafficking of Women and Children in Southeast Asia. UN Chronicle, Volume XL Number 2.

Hosen, M.N (2005), Governance of Indonesian Labour and Migration to Malaysia: An Overview. [Paper in Special Issue: A. Kaur and I.Metcalfe (eds). Migrant Labour in Southeast Asia: Needed, Not Wanted.] IN: Review of Indonesian and Malaysian Affairs, 39(2), pg. 31-34

Santhiago, A (2005). Human Smuggling, Migration and Human Rights: A Malaysian perspective [Paper presented at the review Meeting Migration: Human Rights Protection of Smuggled Persons, Geneva, 25-26 July 2005]

Sheila Devi Michael, Human Trafficking in Malaysia: Trends and Challenges, Proceeding of the Global Conference on Business, Economic and Social Sciences 
Sukma, R. (2008). Southeast Asian Security: An Overview in Changing Security Dynamics in Southeast Asia,Institute for Defence Studies and Analyses.

Skeldon, R. (2000). Trafficking: A Perspective from Asia.International Migration 38, no.1.

The Vienna Forum, United Nations Global Initiative to Fight Human Trafficking, Vienna, Austria, 13-15 February 2008.

National Action Plan Against Trafficking in Persons (2010-2015). Ministry of Home Affairs. http://www.moha.gov.my/images/maklumat bahagian/MAPO/NAP ANTIPEMERDAGANGAN ORANG_2010_2015.pdf.

United Nations on Drugs and Crimes Website, http://www.unodc.org/southeastasiaandpacific/en/topics/illicit-trafficking/human-traffickingdefinition.html 